Research Article

\title{
ADOPTION OF CLIMATE RESILIENT CROPPING PATTERNS IN SOUTHERN COASTAL REGION OF BANGLADESH: FARMER'S' PERCEPTION
}

\author{
J. Sultana, M.B. Ahmed" and M.Y. Ali \\ Agro technology Discipline, Khulna University, \\ Khulna, Bangladesh
}

\begin{abstract}
The study was carried out in Batiaghata upazila of Khulna district to identify different climate resilient cropping patterns that had been practiced over the past three decades as well as the farmers' perception about the causes of adopting climate resilient cropping patterns. Information was collected through personal interview, focus group discussion, systematic study of available records and browsing internet. A slight change was observed regarding climate resilient cropping pattern over the last 30 years in the study area. About 30 years ago, five cropping patterns were practiced, only one pattern (Fallow-Fallow-T. Aman) was found climate resilient. About 20 years ago, 11 cropping patterns were practiced, 5 patterns (Fallow-FallowT. Aman, Boro-Fallow-T. Aman, Boro-Gher (vegetables)-T. Aman, Boro-Gher (vegetables)-Fallow and Fallow-Gher (vegetables)-T. Aman) were found climate resilient. About 10 years ago, 11 cropping patterns were practiced, 7 patterns (Sesame-Fallow-T. Aman, BoroFallow-T. Aman, Boro-Gher (vegetables)-Fallow, Fallow-FallowT.Aman, Boro-Jute-T. Aman, Boro-Gher (vegetables)-T. Aman and Fallow-Gher (vegetables)-T. Aman) were found climate resilient. At present, 14 cropping patterns are being practiced. Out of which, six patterns are climate resilient. Respondents justified nine causes for adopting climate resilient cropping patterns, while increase in cropping intensity was the most significant, while lower input cost was least significant. Most of the respondents (93.80\%) had highly clear perception and the rest $(6.20 \%)$ had moderately clear perception. A positive relationship of education and mass media exposure was observed with their perception.
\end{abstract}

Keywords: Climate, Resilient, Correlation, Cropping, Patterns, Farmers' perception

*Corresponding author: mbaat_ku@yahoo.com

Received: 15.12.2019

Accepted: 06.11.2020 


\section{INTRODUCTION}

Bangladesh is one of the most climatic change affected countries in the world (Kreft et al., 2017). Economy of the country is based on agriculture which is very much sensitive to climate change impact. Adaptation to climate change was ignored initially, but due to the increasing vulnerability of some country's adaptation has recently been covered extensively (Kates, 2000).

During past five decades, agricultural sector in southwestern part of Bangladesh has undergone wide-ranging changes in terms of cropping pattern, cultivation technique, land ownership, intensity of cultivation, and productivity. Although Bangladesh has an agriculture-based economy, yet the contribution of agriculture in GDP has decreased during last few years and now only $16 \%$ of GDP have to rely directly on agriculture (Anonymous, 2016).

In Bangladesh, the major cropping pattern mainly consist of rice based cereal crops (Haque, 1998) for instance, Boro-Fallow-Transplanted man was the major cropping pattern securing 2.31 million ha ( $27 \%$ of Net Cropped Area of the country) including its distribution in 63 districts (Nasim et al., 2017).

The southwestern part of Bangladesh especially Khulna, Bagerhat and Satkhira districts are worst hit by water and soil salinity (SRDI, 2010). While, in past, the stress environment of these areas got very little attention. More food demand brings attention to explore the possibilities of increasing potential of saline lands for increased production of crops due to increased pressure of vast and fast-growing population. Moreover, cultivable land area is decreasing day by day in the country. In this context, there is no other alternative way but to address less favorable and unfavorable environments for food security and to adapt to the climate change. That's why farmers adopt different climate resilient cropping patterns to protect their crops because a choice of appropriate combinations of crops or cropping patterns can be used as an option to minimize the possible devastations and damages from natural calamities such as drought and floods (Mandal, 2010).

The present study was conducted with objectives to identify the cropping patterns over the last 30 years including climate resilient ones and determine farmers' perception regarding the causes of adopting climate resilient cropping patterns.

\section{MATERIALS AND METHODS}

\section{Design and locale of the study}

The present study was a descriptive and diagnostic type of research, based on collection of data by door to door interviewing of the respondents. In this study, two techniques were used: (i) a statistical survey to identify present climate resilient cropping patterns in four villages (Shoilmari, Joikhali, Raingamari and Dorgatola) of Jalma union under Batiaghata upazila of Khulna district and to assess farmers' perception regarding the causes of adopting climate resilient cropping patterns, (ii) 
Focus Group Discussion (FGD) with the participation of local people to find the cropping patterns over the last 30 years.

\section{Population and sampling}

The sample was collected by following multistage disproportionate random method. For data collection, $10 \%$ upazila (out of 9 upazila) in Khulna district were selected and then $10 \%$ union (out of 7 union) from each upazila and $10 \%$ villages (out of 37 villages) in each union were selected. Form 4 villages (10\% of total), 80 farmers (20 from each village) were selected.

\section{Data collection and processing}

Primary data were collected through face to face interview using interview schedule during January to March 2019.

Some of the preferred characteristics of the respondents were considered as independent variables viz. age, educational qualification, family education, family size, farm size, annual income, farming experience and exposure to mass media. Perception of the respondents regarding causes of the adopting climate resilient cropping patterns was considered as dependent variable in this study.

For analysis purpose all qualitative data were converted to quantitative form by using appropriate technique of scoring. In several instances, indices and scales were constructed through the simple accumulation of score assigned to individual or pattern of attributes.

\section{Measurement of selected characteristics (independent variables)}

Among the selected characteristics age was measured in 'actual year', educational qualification in 'years of schooling', family size in 'number', family education in 'years of schooling', farm size in 'hectare', farming experience in 'year', annual income in ' $000 \mathrm{BDT}$ ' and exposure to mass media in 'score'.

\section{Measurement of farmer's perception (dependent variable)}

A 9-item statement was used to determine the respondents' perception regarding the causes of adopting climate resilient cropping patterns. To determine the perception of the respondents' regarding causes of adopting climate resilient cropping patterns Likert's type scale such as agree, strongly agree, undecided, disagree and strongly disagree were used against each of 9 statements. A score of 5, 4, 3, 2 and 1 were assigned against rating scales respectively. The perception score regarding the causes of adopting climate resilient cropping patterns were determined by summing up all scores obtained against each of the 9-statements. The perception score of a respondent could range from 9 to 45 , where ' 9 ' indicate less clear perception and ' 45 ' indicate highly clear perception. On the basis of perception score, the respondents were categorized into three groups as less clear perception $(\leq 15)$, moderately clear perception $(16-30)$ and highly clear perception (>30). To compare statements, a perception index of causes (PIC) was calculated using following formula (Ahmed, 2011): 
$\mathrm{PIC}=\mathrm{N}_{\mathrm{sa}} \times 5+\mathrm{N}_{\mathrm{ag}} \times 4+\mathrm{N}_{\mathrm{ud}} \times 3+\mathrm{N}_{\mathrm{da}} \times 2+\mathrm{N}_{\mathrm{sd}} \times 1$

Where, PIC $=$ Perception Index of Causes of Adopting Climate Resilient Cropping Patterns

$\mathrm{N}_{\mathrm{sa}}=$ Number of respondents indicated as strongly agree

$\mathrm{N}_{\mathrm{ag}}=$ Number of respondents indicated as agree

$\mathrm{N}_{\mathrm{ud}}=$ Number of respondents indicated as undecided

$\mathrm{N}_{\mathrm{da}}=$ Number of respondents indicated as disagree

$\mathrm{N}_{\mathrm{sd}}$ = Number of respondents indicated as strongly disagree

The PIC scores could vary from 80-400. The scores were converted to percentage for clear understanding of the causes that enhance the adoption of climate resilient cropping patterns by using the following formula (Ahmed, 2011):

$$
\text { PI }=\frac{\text { Observed PIC Score }}{\text { Highest Possible PIC Score }} \text { X } 100
$$

\section{Data analysis}

Different statistical treatments such as number, mean, standard deviation, range, minimum, maximum, rank order and percentage were used to describe the variables. To explore relationship between any two variables, Pearson Product Correlation Coefficient (for interval and ratio type of data) was used. The data were analyzed by using Statistical Package for Social Science (SPSS) 20.

\section{RESULTS AND DISCUSSION}

\section{Facts on the selected characteristics of the respondents}

Data presented in Table 1 indicated that most of the respondents $(63.80 \%)$ were old aged, while mean value (56.70) was in between the range of respondents' age (40-80). On the average, 10.18 of deviation from mean value (56.70) was found for age of respondents. Nearly half of the respondents $(48.80 \%)$ had primary level of education followed by secondary level of education $(37.50 \%)$. Mean value of respondents' education (4.85) was tilted to lower level of education, while 4.40 of deviation from mean value (4.85) was found showing most of the respondents had lower level of education. On the contrary, majority of the respondents' family $(58.80 \%)$ had secondary level of education followed by primary level of education $(32.50 \%)$, with mean value in between range values. Majority of the respondents $(61.30 \%)$ had small sized family. Most of the respondents $(91.30 \%)$ had high farming experience, belonged to low income group (80 \%) and had low exposure to mass media $(83.80 \%)$. Mean value of farming experience was at higher but income group and mass media exposure at lower level of range values. Pulok et al. (2008), while he carried out an experiment to find out the causes and consequences of changing cropping pattern in greater Khulna district also found that most of the respondents $(68 \%)$ were old aged. Majlish et al. (2007), found that majority (53\%) of the respondent's family had 
secondary level education while he carried out an experiment on social forestry program.

Table 1. Distribution of the respondents according to their selected characteristics $(\mathrm{N}=80)$

\begin{tabular}{|c|c|c|c|c|c|}
\hline $\begin{array}{l}\text { Selected } \\
\text { Characteristics }\end{array}$ & Categories (Scores) & $\begin{array}{l}\text { No. of } \\
\text { respondents }\end{array}$ & $\begin{array}{l}\text { Distribution of } \\
\text { respondents }(\%)\end{array}$ & Range & $\overline{\mathrm{X}} \pm \mathrm{SD}$ \\
\hline \multirow{4}{*}{ Age } & Young $(\leq 35$ years $)$ & 0 & 0 & \multirow{4}{*}{$40-80$} & \multirow{4}{*}{$56.70 \pm 10.18$} \\
\hline & Middle age (36-50 years) & 29 & 36.30 & & \\
\hline & Old (> 50 years) & 51 & 63.80 & & \\
\hline & Total & 80 & 100 & & \\
\hline \multirow{6}{*}{ Education } & No education $(0)$ & 6 & 7.50 & \multirow{6}{*}{$0-16$} & \multirow{6}{*}{$4.85 \pm 4.40$} \\
\hline & Primary (1-5) & 39 & 48.80 & & \\
\hline & Secondary $(6-10)$ & 30 & 37.50 & & \\
\hline & Higher secondary (11-12) & 2 & 2.50 & & \\
\hline & Above higher secondary (> 12) & 3 & 3.80 & & \\
\hline & Total & 80 & 100 & & \\
\hline \multirow{4}{*}{ Family size } & Small (1-4) & 49 & 61.30 & \multirow{4}{*}{$22-88$} & \multirow{4}{*}{$4.70 \pm 1.29$} \\
\hline & Medium (5-6) & 20 & 25.00 & & \\
\hline & $\operatorname{High}(>6)$ & 11 & 13.80 & & \\
\hline & Total & 80 & 100 & & \\
\hline \multirow{6}{*}{$\begin{array}{l}\text { Family } \\
\text { education }\end{array}$} & No education $(0)$ & 0 & 0 & \multirow{6}{*}{$3-15$} & \multirow{6}{*}{$6.88 \pm 2.49$} \\
\hline & Primary (1-5) & 26 & 32.50 & & \\
\hline & Secondary $(6-10)$ & 47 & 58.80 & & \\
\hline & Higher secondary (11-12) & 5 & 6.30 & & \\
\hline & Above higher secondary $(>12)$ & 2 & 2.50 & & \\
\hline & Total & 80 & 100 & & \\
\hline \multirow{6}{*}{ Farm size } & Landless $(<0.02)$ & 0 & 0 & \multirow{6}{*}{$0.08-2.07$} & \multirow{6}{*}{$0.61 \pm 0.42$} \\
\hline & Marginal (0.02-0.20) & 7 & 8.80 & & \\
\hline & Small (0.21-1.00) & 57 & 71.30 & & \\
\hline & Medium (1.01-3.00) & 16 & 20.00 & & \\
\hline & Large (> 3.00) & 0 & 0 & & \\
\hline & Total & 80 & 100 & & \\
\hline \multirow{4}{*}{$\begin{array}{l}\text { Farming } \\
\text { experience }\end{array}$} & Low experience $(<17$ years $)$ & 3 & 3.80 & \multirow{4}{*}{$15-62$} & \multirow{4}{*}{$39.69 \pm 10.96$} \\
\hline & Medium experience (17-28 years) & 4 & 5.00 & & \\
\hline & High experience (> 28 years) & 73 & 91.30 & & \\
\hline & Total & 80 & 100 & & \\
\hline \multirow{4}{*}{ Income } & Low $(\leq 120)$ & 64 & 80.00 & \multirow{4}{*}{$40-385$} & \multirow{4}{*}{$94.78 \pm 55.67$} \\
\hline & Medium (121-180) & 9 & 11.30 & & \\
\hline & $\operatorname{High}(\geq 180)$ & 7 & 8.80 & & \\
\hline & Total & 80 & 100 & & \\
\hline \multirow{5}{*}{$\begin{array}{l}\text { Media } \\
\text { exposure }\end{array}$} & No exposure $(0)$ & 0 & 0 & \multirow{5}{*}{$2-21$} & \multirow{5}{*}{$7.45 \pm 3.12$} \\
\hline & Low $(1-10)$ & 67 & 83.80 & & \\
\hline & Medium (11-20) & 11 & 13.80 & & \\
\hline & $\operatorname{High}(>20)$ & 2 & 2.50 & & \\
\hline & Total & 80 & 100 & & \\
\hline
\end{tabular}




\section{Climate resilient cropping patterns}

In the study area, 22 cropping patterns were identified over the last 30 years, out of which only 7 cropping patterns are climate resilient according to DAE, Khulna. Before 30 years, 5 cropping patterns were practiced. Among these five (5) cropping patterns, only one (1) pattern was climate resilient (Table 2). About 20 years ago, gher was started in most of the study area and after that time a dramatical change in cropping pattern was observed in the study area. After starting gher in the study area, out of 11 cropping patterns, 5 patterns were climate resilient (Table 2). Before 10 years, out of 11 cropping patterns, 7 patterns were climate resilient (Table 2). Now-adays, 14 cropping patterns are being practiced, out of which 6 patterns are climate resilient (Table 2).

Das et al. (2008), while he carried out an experiment to find out the causes and consequences of changing cropping pattern in greater Khulna district also found the similar cropping pattern over different years.

Table 2. Climate resilient and non-resilient cropping patterns over different years

\begin{tabular}{ll}
\hline \multicolumn{2}{c}{ Climate resilient and non-resilient cropping patterns of 30 years ago } \\
\hline Non-resilient cropping patterns & Climate resilient cropping patterns \\
\hline Sesame+Vegetables -Fallow-T. Aman & Fallow-Fallow-T. Aman \\
Fallow-Aus-T. Aman & \\
Fallow-JoliAus-Fallow & \\
Fallow-Jute-T. Aman & \\
\hline \multicolumn{1}{c}{ Climate resilient and non-resilient cropping patterns of 20 years ago } \\
\hline Non-resilient cropping patterns & Climate resilient cropping patterns \\
\hline Sesame+Vegetables -Fallow-T. Aman & Fallow-Fallow-T. Aman \\
Fallow-Aus-T. Aman & Boro- Fallow- T. Aman \\
Boro- Aus-Fallow & Fallow-Gher (Vegetables)- T. Aman \\
Fallow-Jute-T. Aman & Boro-Gher (Vegetables)-Fallow \\
Vegetables+Mustard/Mung- Fallow- & Boro-Gher (Vegetables)- T. Aman \\
Fallow & \\
Wheat- Fallow-T. Aman & \\
\hline
\end{tabular}


Climate resilient and non-resilient cropping patterns of 10 years ago

Non-resilient cropping patterns

Boro- Aus-Fallow

Vegetables+Mustard/Mung- Fallow-

Fallow

Wheat- Fallow-T. Aman

Fallow- JoliAus-Fallow
Climate resilient cropping patterns

Fallow-Fallow-T. Aman

Boro- Fallow- T. Aman

Fallow-Gher (Vegetables)- T. Aman

Boro-Gher (Vegetables)-Fallow

Boro-Gher (Vegetables)- T. Aman

Sesame- Fallow-T. Aman

Boro-Jute-T. Aman

\begin{tabular}{ll}
\hline \multicolumn{2}{c}{ Present climate resilient and non-resilient cropping patterns } \\
\hline Non-resilient cropping patterns & Climate resilient cropping patterns \\
\hline Fallow-Fallow-Vegetables & Fallow-Fallow-T. Aman (45\%) \\
Vegetables+Sesame- Fallow-Fallow & Boro- Fallow- T. Aman (35.25\%) \\
Vegetables+Mung- Fallow-Fallow & Fallow-Gher(Vegetables)-T. Aman \\
Mung- Fallow- T. Aman & Boro-Gher (Vegetables)-Fallow (40\%) \\
Vegetables-Fallow-T. Aman & Boro-Gher (Vegetables)-T. Aman \\
Mustard+Mung- Fallow -T. Aman- & $(1.25 \%)$ \\
Mustard+Mung- Fallow- Fallow & Sesame- Fallow-T. Aman (28.75) \\
Boro-Fallow-Fallow & \\
\hline
\end{tabular}

In the study area, at present 6 climate resilient cropping patterns are found to be adopted by the respondents in different extent. Fallow-Fallow-T.Aman was the most dominant cropping pattern which was practiced by $45 \%$ of the respondents. The second dominant pattern was Boro-Gher (Vegetables)-Fallow which was practiced by $40 \%$ of the respondents, followed by Boro-Fallow-T. Aman (35.25\%), SesameFallow-T.Aman (28.75 \%). Fallow-Gher (Vegetables)-T. Aman (1.25\%) and BoroGher (Vegetables)-T. Aman (1.25\%) were adopted by very few respondents.

Rashid et al. (2017) also found the similar result that, Fallow-Fallow-T.Aman, FallowT.Aman-Boro, Boro-Fish-Fish, Fallow-T.Aman-Sesame and Gher (Vegetables)-T. Aman-Boro are the dominant cropping patterns in Khulna region.

\section{Farmer's perception regarding the causes of adopting climate resilient cropping patterns}

The overall perception scores of the respondents for causes of adopting climate resilient cropping patterns varied from 30- 40 against the possible range of 9-45 on an 
average. Mean value of clear perception (35.65) was in between range of perception of respondents (30-40). On the average, 1.89 deviation was found from mean value (35.65) of perception of respondents for causes of adopting climate resilient cropping patterns, which was very low (Table 3 ). An overwhelming majority of the respondents $(93.80 \%)$ had highly clear perception while the rest $(6.20 \%)$ had moderately clear perception about the causes of adopting climate resilient cropping patterns. No respondent was found to have less clear perception (Table 3), showing thereby that respondents had clear perception to adopt climate resilient cropping patterns. A similar observation was reported by Afique et al. (2006) while he carried out an experiment to determine the perception of rural women on the benefit of agricultural model farm activities of Sabalam by Unnayan Samity (SUS) also found that most $(97.5 \%)$ of the respondent rural women had highly clear perception while only $2.5 \%$ had moderately clear perception. Majlish (2007), also found that majority (59\%) of the respondents had highly clear perception on social forestry program.

Table 3. Distribution of the respondents according to their perception for causes of adopting climate resilient cropping patterns

\begin{tabular}{|c|c|c|c|c|c|}
\hline \multirow{2}{*}{ Categories } & \multirow{2}{*}{ Score } & \multicolumn{2}{|c|}{ Respondents $(\mathrm{N}=80)$} & \multirow{2}{*}{$\overline{\mathrm{X}} \pm \mathrm{SD}$} & \multirow{2}{*}{ Range } \\
\hline & & Number & Percentage & & \\
\hline Less clear perception & $1-15$ & 0 & 0 & & \\
\hline Moderately clear perception & $16-30$ & 5 & 6.20 & $35.65 \pm 1.89$ & $30-40$ \\
\hline Highly clear perception & $>30$ & 75 & 93.80 & & \\
\hline Total & & 80 & 100 & & \\
\hline
\end{tabular}

Rank order of the statements based on perception score of the farmers related to the causes of adopting climate resilient cropping patterns

Data based on the Farmers' Perception Index (PI) score (Figure 1) indicated that the farmers had almost similar perception regarding causes of adopting different climate resilient cropping patterns except lower input cost. Ranking of causes expressed by farmers were increase in cropping intensity, sustainable increase in crop production, year-round distribution of labor, the livelihood of people is increasing, and crops are less prone to natural disaster, lower yield of climate susceptible variety, neighborhood aspects and short life cycle of resilient varieties. Low input cost was expressed significantly lowest perception of cause by the farmers. 


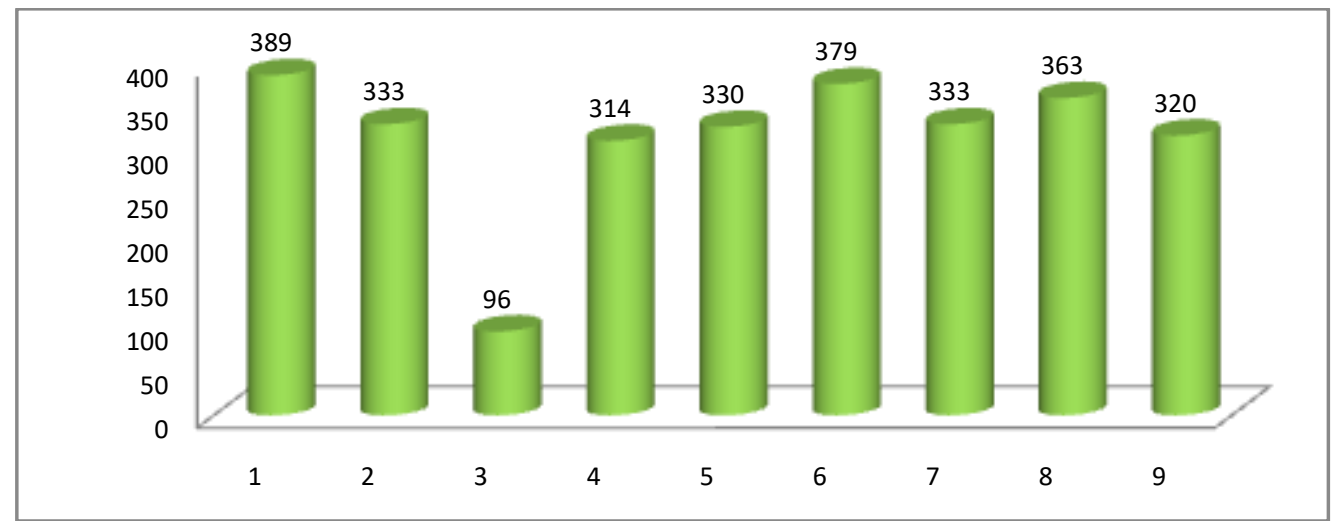

Figure 1. Relative position (rank order) of the statements related to perception regarding the causes of adopting different climate resilient cropping patterns

$\mathbf{1}=$ Increase in cropping intensity $\left(1^{\text {st }}\right), \mathbf{2}=$ Crops are less prone to natural disaster $\left(4^{\text {th }}\right), \mathbf{3}=$ Lower input cost $\left(8^{\text {th }}\right), \mathbf{4}=$ Short life cycle of resilient varieties $\left(7^{\text {th }}\right), \mathbf{5}=$ Lower yield of climate susceptible cropping patterns $\left(5^{\text {th }}\right), \mathbf{6}=$ Sustainable increase in agricultural production $\left(2^{\text {nd }}\right), 7=$ The livelihood of people is increasing due high income from per unit area of land $\left(4^{\text {th }}\right), \mathbf{8}=$ The year round distribution of labor and machinery $\left(3^{\text {rd }}\right), \mathbf{9}=$ Neighborhood aspects: Changes in the farming practices and adoption of climate resilient cropping patterns in the neighboring areas induce other farmers to adopt $\left(6^{\text {th }}\right)$.

\section{Relationship between the selected characteristics of the respondents and their perception regarding causes of adopting climate resilient cropping patterns}

Data presented in Table 5 showed that among 8 selected characteristics of the respondents, only education and mass media exposure showed a significant positive relationship with their overall perception.

Table 4. Correlation between the selected characteristics of the respondents and their perception regarding causes of adopting climate resilient cropping patterns

\begin{tabular}{lll}
\hline $\begin{array}{l}\text { Independent variable ((the selected } \\
\text { characteristics) }\end{array}$ & $\begin{array}{l}\text { Dependent variable } \\
\text { (Focus variable) }\end{array}$ & $\begin{array}{l}\text { Correlation } \\
\text { coefficient }(\mathrm{r})\end{array}$ \\
\hline Age & Perception regarding & $0.089 \mathrm{NS}$ \\
Education & causes & $-0.039 \mathrm{NS}$ \\
Family size & of adopting climate & $0.093 \mathrm{NS}$ \\
Family education & resilient cropping & $0.089 \mathrm{NS}$ \\
Farming experience & patterns & $-0.009 \mathrm{NS}$ \\
Farm size & & $0.145 \mathrm{NS}$ \\
Income & & $0.317^{* *}$ \\
\hline
\end{tabular}

$\mathrm{NS}=$ Non-significant, $* *$ Correlation highly significant at $1 \%$ level of probability and *Correlation highly significant at $5 \%$ level of probability. 
Table 4 shows that the higher is the level of education and mass media exposure, higher is the perception regarding the causes of adopting climate resilient cropping patterns. This might be due to the fact that education and mass media exposure broadens the knowledge of the people to understand the benefits of climate resilient cropping patterns. The findings of the studies conducted by Ahmed, (2011); Adeola, (2012) and Majlish, (2007); have harmony with the present study regarding educational qualification. Similar result regarding mass media exposure were described by Karim, (2008); Chowdhury, (2009), Kamali, (2011);

\section{CONCLUSION}

An increasing trend in total number of climate resilient cropping patterns from 30 years ago to 10 years ago was observed but it was found to be decreased at present. The respondents had clearer perception regarding causes of adopting climate resilient cropping patterns. Among identified 9 causes of adopting climate resilient cropping patterns, all had almost similar PS (ranging 314-389) except that of lower cost input (96). An overwhelming majority of the farmers had highly clear perception $(93.80 \%)$. followed by moderately clear perception $(6.20 \%)$. Only education and mass media exposure of the respondents showed a significant positive relationship with their perception regarding causes of adopting climate resilient cropping patterns. Finally, it could be concluded that there are a lot of causes that affected the adoption of climate resilient cropping patterns and accelerated to change in adoption.

\section{REFERENCES}

Adeola, R.G. (2012). Perceptions of environmental effects of pesticides use in vegetable production by farmers in ogbomos, Nigeria. Global Journal of Science Frontier Research: Agriculture and Veterinary, 12(4):73-78

Afique, A.A. (2006). Rural women's perception of benefit from agricultural model farm profect of Sabalamby Unnayan Samity. M.S Thesis, Department of Agricultural Extension Education, Bangladesh Agricultural University, Mymensingh.

Ahmed, M.B. (2011). Impact of shrimp farming on socio-economic agriculture and environmental conditions of paikgacha upazila of Khulna district. Ph.D. Thesis, Department of Agricultural Extension and Rural Development, Bangabandhu Sheikh MujiburRahman Agricultural University, Gazipur, Bangladesh.

Alam, M.N. (2008). Farmers' perception of soil quality degradation due to less use of organic materials. M.S Thesis, Department of Agricultural Extension Education, Bangladesh Agricultural University, Mymensingh. 
Anonymous, (2016). Statistical Yearbook of Bangladesh; poverty escape pathways and livelihood improvement. Pub. By: Anjuman Ara, D-186/7, Nazrul Sarani, Middle Sayabithi, Joorpukur, Gazipur 1700, Bangladesh.

Chowdhury, A.R. (2009). Farmers' Perception of Utilizing Nutrient Sources for Integrated Plant Nutrient System towards Sustainable Crops Production. Ph.D. Thesis, Department of Agricultural Extension Education, Bangladesh Agricultural University, Mymensingh.

Das, P.K. (2008). Causes and consequences of changing cropping pattern in greater Khulna district. M.S Thesis, Department of Agronomy, Khulna University, Khulna.

Haque, M.S. (1998). Integrated nutrient management with inorganic and bio fertilizers in legume based cropping patterns. Proceedings of the national workshop on integrated nutrient management for crop production and soil fertility.24-25 March 1998. BARC, Gazipur. Pp. 99-109.

Kamali, M.H.K. (2011). Farmers' perception on harmful effects of using agrochemicals in boro rice cultivation in Bangladesh. Ph.D.Thesis, Institute of Bangladesh Studies, University of Rajshahi, Rajshahi, Bangladesh.

Karim, M.R. (2008). Farmers' Perception of Quality and Marketing System of RDRS Seed. M.S Thesis, Department of Agricultural Extension Education, Bangladesh Agricultural University, Mymensingh.

Kates, R.W. (2000). Cautionary Tales: adaptation and the global poor. In Societal Adaptation to Climate Variability and Change. Pp. 517.

Kreft, S., Eckstein, A. and Melchior, I. (2017). Global climate risk index 2017: who suffers most from extreme weather events? Weather-related loss events in 2015 and 1996 to 2015. German watch, Bonn.

Majlish, S.A.K. (2007). Perception of participant women on social forestry program of BRAC.M.S Thesis, Department of Agricultural Extension Education, Bangladesh Agricultural University, Mymensingh.

Mandal, R. (2010). Cropping patterns and risk management in the flood plains of Assam. Economic and Political Weekly. August, vol. xlv No 33.

Nasim, M., Shahidullah, S.M., Saha, A., Muttaleb, M.A., Aditya, T.L., Ali, M.A. and Kabir, M. S. (2017). Distribution of Crops and Cropping Patterns in Bangladesh. Bangladesh Rice Journal, 21(2):1-55.

Rashid, M.H. (2017). Cropping systems and their diversity in khulna region. Bangladesh Rice Journal, 21(2):203-215.

SRDI, (2010). Saline Soils of Bangladesh. Soil Resource Development Institute, Farmgate, Dhaka-1215. Pp. 55. 